\title{
Amelioration of acid soils - alternative approaches
}

\author{
Yu. Tsapko, \\ Doctor of Biological Sciences \\ K. Desiatnyk, \\ A. Ogorodnia, \\ B. Meshref Radvan \\ National Scientific Center «Institute of Soil Science and Agrochemistry named after O.N. \\ Sokolovsky»
}

The purpose. To study alternative approaches to amelioration of acid soils. Methods. Analyticalsynthesizing (research of change of properties of soils under influence of amelioration), comparativeanalytical (comparison of influence of alternative approaches of amelioration of acid soils on their soil parameters), general scientific (system, complex) and calculative. Results. Results of researches of application of calcium containing production wastes and local source of raw materials as improvers upon acid soils are generalized. Characteristics and mechanism of action of biomeliorative influence of cultures-phyto-improvers upon structurally-aggregation state of podzolized soils are resulted. Conclusions. It is determined that the most effective and ecologically safe calcium containing improvers are dolomite, defecate and limestone flux in doses determined according to charts of $\mathrm{pH}$ buffering. It is fixed that the most effective structure-creating properties have Lucerne, Sainfoin and Mustard.

Key words: amelioration, acid soils, calcium containing waste, cultures-phyto-improvers, buffering.

One of the most important tasks of modern agrarian science is the search for ways to preserve and reproduce soil fertility based on the principles of resource conservation and environmental safety. According to various estimates [1], soils with shifted acid-base equilibrium in the acidic side occupy a significant share (up to 8,5 million hectares) of Ukraine's soil-resource potential. The acidic soil environment negatively affects the physical and chemical properties, biological activity, intensifies the processes of washing of bivalent cations, heavy metals and radionuclides in groundwater, which is accompanied by loss of fertility and significantly degrades the agroecological state of the surrounding ecosystems.

Due to the widespread distribution of acid soils in the structure of agricultural land of Ukraine and the high cost of existing and often unbalanced methods of acid soils melioration, the problem of finding alternative approaches to their melioration arises. Solving the problem requires differentiated reclamation measures, taking into account agroecological and morphogenetic features of soils.

In line with the foregoing, we focus on the scientific substantiation of the use of calcium-containing ameliorants, taking into account environmental risks, phytomelioration measures and some aspects of structural melioration.

METHOD

The following soils were selected as the objects of research: podzolized heavy-gravel black soil $(\mathrm{pH}$ $5,9)$, podzolized sandy loam ( $\mathrm{pH} 5,4)$, and light gray surface-gelatinous $(\mathrm{pH} 4,0)$. Soil samples were taken in a three-time repeat drill (DSTU ISO 10381-2: 2004), from which the intermediate samples were prepared from the individual samples (DSTU 4287: 2004), which were used for further determination of such soil characteristics: the structural and aggregate composition of the soil was determined by the Savinov's method (MVB 31-497058-012-2005) - fractionation of soil in air-dry state (dry sieving); the number of microarthropod in the soil was determined in accordance with generally accepted standard methods of soil and zoological research (D. G. Zvyagintsev, I. P. Babieva, G. P. Zenova, 2005; Yu. B. Bizova, M. S. Gilyarov, B. Dungen, 1987). The calculation of soil invertebrates (Aporrectodea caliginosa) was carried out by the method of excavation and manual disassembly of soil samples by the method of M.S. Gilyarova, 1987.

\section{RESULTS AND DISCUSSION}

The traditional method of improving the state of acid soils is chemical melioration (in particular liming), which is a rather costly measure, and without proper scientific justification, it can lead to negative environmental effects [2]. The latter encourages scientists and specialists in the agrarian sector to develop alternative, relatively inexpensive, environmentally safe reclamation measures. That is why we 
carried out research on the most common calcium-containing waste products in Ukraine and local raw materials as ameliorants on acid soils and identified the most efficient and environmentally safe ones.

As a result of studies on different degrees of acidity of soils in Ukraine, it is determined that the use of dehydrated lime, reclamation, which is traditional in Ukraine, is a rather unprofitable land reclamation measure from an economic point of view. So, with a one-time introduction, the damage reaches up to 3 thousand $\mathrm{UAH} / \mathrm{ha}$ in three years, which is due to the high cost of its production, and hence the high market price (more than 1 thousand hryvnia per ton). At the same time, cement production is well developed on the territory of Ukraine, the removal of which consists of dust from electrofilters, which contains a significant amount of calcium and has an alkaline reaction of the medium. In the absence of the need to process this waste product and its high neutralizing capacity, in today's market conditions, its application is an attractive innovative alternative to traditional limestone ameliorants, especially in areas located near cement plants. The research conducted in the Kharkiv region, it was established that the introduction of cement dust from the Balaklievsky cement plant on chernozem under sugar beet over three years yielded 3.6 thousand $\mathrm{UAH} / \mathrm{ha}$.

At the same time, given the fact that the content of $\mathrm{Cr}, \mathrm{Cu}$ and $\mathrm{Ni}$ in the composition of cement dust is higher background content in the studied soils (podzolized lacustrine, clear-gray forest-loamy loam and black earth, podzoles heavy-soot), there is an ecological risk soil contamination. In our opinion, this waste production should be used only on high-buffer podzolized soils of the forest-steppe and only before the introduction of crop rotation with calcium cultures.

It has been established that a promising reclamation is a fine-grained limestone fraction, or flux limestone, which is formed by the production of glass and accumulates in significant quantities at glass factories. This production residue is a remnant of a small fraction of limestone from natural spots, which is not involved in the technological process of glass production, that is, it is practically a land improvement material of high ecological quality of natural origin with low cost. Our research on different soils of Ukraine showed a high growth of crop when using this reclamation for common crops in Ukraine (sugar beet, barley, corn). At the same time, with the application of this reclaimer, increased biological activity of the soil was detected. So, for example, the number of soil microarthropod (columbol and oribatid) in chernozem is podzolenom, without the use of lime ameliorants is $160-320 \mathrm{ek} / \mathrm{m} 2$, the single introduction of limestone flux contributes to their increase to 640-970 ek / m2 during three years. On sod-podzolic soils, without the introduction of limestone meliorants, oribatides are practically absent, the maximum number reaches only $40 \mathrm{ex} / \mathrm{m} 2$, at the same time, when adding limestone flux their number increases to 160-240 copies / m2. Also, this meliorant has also had a positive effect on the conditions of the existence of Aporrectodea caliginosa soil lumbricides, while their introduction varies in the range from 32 to 70 per $\mathrm{m} 2$ in the range of 9-32 per $\mathrm{m} 2$ per control.

Every year, in Ukraine, the problem of accumulation of red slurry as a result of the Mykolayiv Alumina Factory is becoming global in scale, the annual output of this product exceeds 1 million tons. At the same time, more than 15 million tons of it is accumulated in reservoirs that are overcrowded and constitute not only ecological danger, but also poses a threat of man-made disaster, a similar accident in October 2010 at the metallurgical plant for the manufacture of aluminum Ajkai Timfoldgyar Zrt (Hungary). One of the options for its utilization during the last 10 years was considered its use as a reclamation on acid soils. However, the studies conducted by us have shown that the use of red mud as a reclamation has a detrimental effect on soil biota and has a low level of profitability (profit - $543 \mathrm{UAH} / \mathrm{ha}$ in three years), that is, it is not profitable both from the ecological point of view and from the economic point sight

The high economic effect was detected from the use of dolomite and defecate; the profit for three years amounted to $2366 \mathrm{UAH} / \mathrm{ha}$. and $1960 \mathrm{UAH} / \mathrm{ha}$, respectively. Despite the high cost of dolomite, the effect of its application, which manifests itself in improving the vital functions of soil biota, the development of positive microflora and the establishment of an optimal ratio of microbial groups, saturation of the colloidal complex on calcium and magnesium, improving the physical and physical and chemical characteristics of the soil, and as a result significant increase in yield, makes this ameliorant one of the most perspective ameliorants on the territory of Ukraine.

Also, in the field of chemical melioration of acidic soils, an important issue is the optimization of the dose of calcium-containing ameliorants. The introduction of lime ameliorants in doses determined according to buffer schedules facilitates the establishment of optimal $\mathrm{pH}$ indices for selected crops and the improvement of calcium nutrition on all studied soils. This method takes into account not only the characteristics of the soil (as in the case of determination of norms for hydrolytic acidity), but also the characteristics of agricultural crops and ameliorants themselves [3]. At the same time, this method is most 
appropriate from an environmental point of view, since its application minimizes the negative impact of chemical melioration on the quality of groundwater.

Another promising measure in preserving and reproducing soil fertility and improving their agroecological status is the biological methods of melioration $[4,5]$, among which the phytomelioration is one of the important places, whose biomeliorative effect is due to the use of the phytopotential of competently harvested crops. Relatively mild and environmentally friendly, compared with chemical melioration.

In practice, phytomelioration is most effective on weakly acid soils when this measure is carried out through optimization of the structure of crop areas and by the selection and placement in crop rotation of crops resistant to high acidity in the soil $[6,7]$. The most effective phytomelirant cultures for improving the physicochemical properties of podzolic soils are alfalfa, sainfoin; agro-physical - alfalfa, sainfoin, mustard and agrochemical - alfalfa, sainfoin, lupine, soybeans. These phytomelirants differ in types of the root system, the nature of their distribution by profile, and so on. The root system of perennial legumes and sudan grass is highly developed and densely permeates the soil profile. The main mass of roots of annual cultures (lupine, soya, mustard) is located in the upper, most biologically active humus horizon.

The biomolecular effect of plants is that they contribute to the accumulation of humus in the soil, with their not even prolonged (1-3 years) cultivation, the properties of the soil improve: acidity decreases; the supply of nutrients increases; absorption capacity, buffering, moisture capacity and water permeability are improved; there is a change in the microflora, as a result of which its biological activity increases and aggregate composition improves [8]. For example, the largest number of valuable from the agronomic point of view of structural aggregates $(10-0,25 \mathrm{~mm})$ in a layer of soil $0-20 \mathrm{~cm}$ recorded under alfalfa. The sum of aggregates $10-0,25 \mathrm{~mm}$ in this variant amounted to $86.8 \%$ in the first year and $89.2 \%$ - after two years of use of culture, and during the third year of cultivation, this figure practically did not change. At the same time, it was noted that an increase in the sum of agronomically valuable structural aggregates was accompanied by a decrease in the dust fraction - after two years it was $0.8 \%$ of the total aggregates.

The mechanism of the influence of phytomelirants on the structural and aggregate composition of podzolized soils is manifested: under perennial herbs, through the translocation («tightening» of calcium compounds (an important factor of soil structure formation) from the lower horizons to the upper ones; under the mustard - due to its own root extracts, which contain essential oils that can «stick» structural units. Perennial grasses and mustard plants the soil by means of bilateral action, on the one hand due to the separation of large aggregates (mechanical impact), and, on the other hand, the activation of the opposite process, the combination of small aggregates in agronomic-valuable, that is, reduction of the dusty fraction. This fact indicates that mustard is not only a good siderate, but even without disturbing, it can positively influence such an indicator of the physical state of the soil as the structure.

The cultivation of Sudan grass leads to a decrease in the number of deep aggregates due to their destruction and spraying. In our opinion, one of the reasons for this phenomenon is a powerful, bluish root system of culture, which very thickly penetrates the upper layer of soil and also strongly dries it, which makes it impossible to form large aggregates in full. In addition, due to the selection of phytomelirants with well-developed root systems, their influence on the processes of formation in the lower soils of the soil, where the effect of climatic factors is weakly expressed, is revealed. The sum of agronomic-valuable aggregates under study phytomelirants in the soil layer of $20-60 \mathrm{~cm}$ in the range of 1.3-2.8 times was higher compared to the control.

Thus, depending on which fraction predominates in the soil - brilevate or pollen, it is possible to adjust the direction of structure formation through the selection of crops. If the problem of blubber aggregates can be solved to a greater or lesser extent due to the mechanical action of the root system of crops (Sudan grass, mustard and perennial grasses), then alfalfa, espresso and mustard should be grown for soils with a predominantly dusty fraction.

Calculations of the economic efficiency of phytomelioration use indicate that only crops grown on grain (lupine, soybeans and mustard) are profitable for the first year of cultivating crops, while perennial grasses and Sudan grass when cultivated on hay are unprofitable. However, taking into account the twoyear after-effects, we note that phytomedication techniques are fully paid off - despite the lack of fertilizers, ameliorants and chemical protection of crops. The highest level of profitability from the cultivation of mustard, soybean and lupine $128.81-62.3 \%$.

Structural amelioration, first of all, claying, mooring, peating, forestry, etc., is one of the powerful measures for radically improving the agroecological state and increasing the fertility of turf-podzolized soils of light granulometric composition. It should be noted that the positive effect of structural melioration on the physical, chemical, chemical, physical and biological properties of podzolized soils, binder-pitch, 
sandy loam and granulometric composition is well-known [9, 10]. At the same time, the influence of structural melioration on the buffer properties of soils remains insufficiently investigated. That is why, given the special importance of increasing the buffer capacity of soils of light granulometric composition, research in this direction has significant prospects.

\section{Conclusions}

The necessity of liming acid soils is obvious, and the cessation of the state program on liming of acid soils due to lack of funds entails a number of environmental risks, therefore, in the current economic conditions, the most promising and efficient, and most importantly environmentally safe is the use of dolomite, defecate and limestone flux in the norms defined for graphs of buffer $\mathrm{pH}$.

The use of phytomelioration methods for acidification of soil cultivation contributes to solving three main problems of modern agricultural production: the reproduction of soil fertility, improvement of its agroecological status and provision of a forage base for livestock breeding.

\section{Bibliography}

1. Fundamentals of soil fertility management: monograph / R. S. Truskavetskiy, Yu. L Tsapko; after scien. red. of R. S. Truskavetskiy. - Kh.:FOP Brovin O. V., 2016. - 388 p.

2. Balyuk S. Scientific approaches to the soil degradation assessment (with Ukrainian Reclaimed Lands as an Illustration) / S. Balyuk, R. Truskavetsky, M. Zakharova // Progress in Managing Water for food and Rural Development: materials 23-rd European conference (17-24 May 2009 , Lviv). - Lviv, 2009. - P. 70.

3. Truskavetskiy R. S. Soil buffer capacity and their main functions. Kh.: Nove slovo, 2003. -225 p.

4. Mirza B. B. Rehabilitation of soils through environmental friendly techonologies: role of sesbania and farm yard manure / B. B. Mirza, M. S. Zia, N. Szombathova, A. Zaujec // Agricultura Tropica et Subtropica. - 2005. - Vol. 38(1). - P. 12-16.

5. Kumar A. Growth, biomass and chemical composition of selected forage grass species as affected by salinity stress. / A. Kumar, P. C. Sharma // CSSRI Annual Report. - 2004-2005. - P. 46-47.

6. Lucerne and clover / B. S. Zinhenko, V. S. Klyuy, Y. I. Matskiv [and others]. - K.: Urozhay, 1989. $240 \mathrm{p}$.

7. Savvinov N. I. Savvynov N. I. The influence of perennial grasses and some agrotechnical methods on the strength of soil structure in different zones / N. I. Savvinov. - M. : Selhoziz, 1936. -356 p.

8. Oorodnya A. I. Features of accumulation-dissipation of the main elements of nutrition in chernozem podzolenym heavy-bulk under the influence of phytomelirants / A. I. Ogorodnya // Arohimia I runtoznavstvo. - 2015. - № 82. - P. 125-128.

9. Mazur G. A. Reproduction and regulation of the fertility of light soils: Monograph. - K.: Agrarna nauka, 2008. - $208 \mathrm{p}$.

10. Breure A. M. Soil Biodiversity: Measuremrnts, Indicators, Threats And Soil Functions / A. M. Breure // Soil and Compost Eco-Biology: Materials i International Conference (15 - 17 September 2004, León - Spain). - León - Spain, 2004. -P. 83-96. 